értelmezéshez azonban fontos és szükséges a szótári minősítések pontos ismerete (ezért is érdemes a szótárak bevezetőjét, felhasználási segédletét elolvasni, az értelmezéshez használni), amelyek részletes leírására, valamint kritikai elemzésére jelen tanulmány keretei között nem vállalkozok.

(Folytatjuk.)

M. PINTÉR TIBOR

Károli Gáspár Református Egyetem

\title{
TUDOMÁNYTÖRTÉNET
}

\section{Tradíció és modernség az Ungarische Jahrbücher nyelvészeti írásaiban}

\section{A funkcionális szemlélet kibontakozása a berlini mühelyben}

1. Mielőtt az UJB. nyelvészeti írásainak bemutatását tovább folytatnám, engedtessék meg egy személyes megjegyzés. Fiatal nyelvész/nyelvtanárként, illetve a tudománytörténet iránt érdeklődő kutatóként feltünt, hogy a magyarnyelv-oktatás folyamatában körülbelül a 20. század első dekádjától kezdve megtorpanás érezhető. A magyar mint idegen nyelv tanításának korai, csúcspontját a 19. század dereka-vége felé elérő íve a rákövetkező évszázad elejétől kezdve szakadozni látszik. A Brassai-féle leírási metódus, mely összegezte, elméletté gyúrta a külső perspektívából szemlélt, a funkciót tertium comparationisként használó, inter- és intralingvális összevetésre alkalmas megközelítéseket, lassan háttérbe szorult, fokozatosan átadta helyét az egyre statikusabb rendszernek. E változás egyáltalán nem kedvezett sem az iskolai anyanyelvi, sem az idegen nyelvi oktatásnak. Kellő mélységü kutatás híján csak gyanítottam, hogy a megtorpanás nem jelent végleges szakítást a korábbi folyamattal.

Az UJB. évfolyamainak vizsgálata megerősítette feltételezésem: míg Magyarországon ez idő tájt meglehetősen háttérbe szorulnak az általános nyelvészeti kérdések, a funkcionális szemlélet szinte eltünni látszik, addig a berlini folyóiratban mindez sokkal erőteljesebben van reprezentálva. Az UJB.-re nem áll KIEFER megjegyzése: „A század első felében müködő nyelvészek kevés kivétellel nem mutattak érdeklődést a nyelv általános kérdései iránt" (KIEFER 2002: 12). Tanulmányom második részében ${ }^{1}$ erre a progresszív irányra helyezem a hangsúlyt, mert meggyőződésem szerint itt teljesedik ki a folyóirat modern nyelvészeti látásmódja.

2. Az Ungarische Jahrbücher nyelvre vonatkozó írásait áttekintve leszögezhetjük, hogy a tradíció a német összehasonlító nyelvészettel való szoros kapcsolatot jelentette. A szerzők a nyelvrokonság feltérképezéséhez minden rendelkezésre álló adatot egyenlő súllyal vizsgáltak, a tanulmányok alapján nem következtethetünk bármilyen prekoncep-

\footnotetext{
${ }^{1}$ Első rész: HEGEDÜs 2018: 77-86.
} 
cióra. Ebben az időszakban az eredetkérdésben az ural-altáji nyelvrokonság az elfogadott paradigma, így természetes, hogy különösen az első időszakban a török kapcsolatok kerültek a vizsgálatok fókuszába, legyenek azok pusztán nyelvi vagy egyéb kultúrtörténeti jellegüek. Fontos leszögezni: a törökségi, illetve a finnugor nyelvekkel való összehasonlítások eredményei sohasem „vagy - vagy” relációban jelentek meg. A kutatási célokat GRAGGER munkaterve egyértelműen megfogalmazza: „Vizsgálni kell a finn-ugor-indogermán rokonság problémáját; a finnugornak legrégebbi, az ural-altáji és az indogermán nyelvekhez füződő kapcsolatait; a magyarban az iráni, a kaukázusi, a volgai (kuban-) bolgár, a szláv , az ó- és középfelnémet, latin, olasz, oszmán, bajor-osztrák valamint a legújabb jövevényszókat; a szomszédos nyelvekben fellelhetö magyar elemeket; a nyelvemlékeket, a nyelvföldrajzot, az írott nyelv kialakulását, valamint történeti és összehasonlító nyelvészet egyéb kérdéseit." (GRAGGER 1921: 5).

A rokonság felderítésén túl, azzal egyenrangú kutatási témaként kezeli a magyarság sajátságos földrajzi elhelyezkedéséből adódó kulturális hatások vizsgálatát: „A magyarok faj- és nyelv tekintetében Európában elszigetelt, három nagy kultúrkör által körülvett nép. A német, olasz és bizánci-szláv kultúrkör közepette, velük szervesen összenőve alakította ki egyedi, a többiekétől eltérő jellegzetességét, és ezáltal Európa kulturális összképébe sajátos színt hozott" (GRAGGER 1925: 27).

2.1. Az UJB. első periódusa - azaz a Gragger haláláig tartó időszak (1926) - tanulmányai nagy vonalakban megfelelnek BAKRÓ-NAGY (2012: 305) jellemzésének: „A 20. század első korai évtizedeiben a finnugrisztikai vizsgálódások fő célja a finnugor nyelvek eredetének újgrammatikus és pozitivista elvek alapján történő leírása volt." Az alaposabb elemzés során azonban az arányok eltolódását látjuk: Az újgrammatikus iskola alaptételei közül egyértelmüen elvetik a hangváltozások kivételnélküliségét; ebből következően az analógiás változások magyarázatában egyre erőteljesebben támaszkodnak a nyelvhasználat nem nyelvistruktúra-függő tényezőire. „Az analógia az újgrammatikus felfogásban a beszélők képzettársításait megjelenítő tényező. Egész pontosan olyan egyedi asszociációkra utal, amelyek a nyelvek történetének minden időszakában felléphetnek, így bármikor megzavarhatják a hangtörvények általános érvényesülését. E szerint az elsősorban hangfiziológiai jellegű mechanizmusokon olykor más, tisztán pszichikai eredetű folyamatok kerekednek felül." FeHÉR (2018: 33) rendkívül világos elemzése itt az újgammatikus iskola hangtörvényekre vonatkozó megállapításaira vonatkozik, ugyanakkor mintegy megelőlegezi az UJB. tanulmányaiban a közös pontot: „Noha az igen színvonalas munkát végző, manapság is elismerésre méltó új-grammatikusok a két fő elvvel együttesen bármilyen jelenséget le tudtak írni, azt is meg kell jegyezni, hogy „magyarázataik" anélkül ragadtak meg valami nagyon lényegeset a változási folyamatokból, hogy tényleges oksági (kauzális) érvelések lettek volna. Az ugyanis mindvégig feltáratlan maradt, hogy - akár egy-egy konkrét esetben, akár általában véve - mi motiválhatja a hangtörvények, hangváltozási tendenciák, és mi az analógia megjelenését" (FEHÉR 2018: 35). Az UJB. nyelvészeti cikkeinek újdonsága abban rejlik, hogy nem elégszenek meg pusztán az okok keresésével, hanem kitágítják a cél irányába is, azaz ötvözik a kauzális és finális argumentumokat (1. LEWY 1928: 274). Ennek egyik eszköze a képzettársítások beépítése a nyelv fejlődésének/mozgásának magyarázatába, mely az UJB. szerzői számára az idő haladtával egyre természetesebb eljárássá válik (1. THIENEMANN). A pozitivista szemlé- 
let a tények, adatok objektív, szigorú tárgyilagosságra törekvő leírásában nyilvánul meg, mely különösen érződik a tipológiai indíttatású kutatásokban.

Az UJB. modernségét, előremutató tendenciáját e sajátos interdiszciplinaritásában látom: a 19. századi összehasonlító nyelvtörténet eredményeitől és módszereitől elindulva dolgozza fel az objektív szempontok szerint gyüjtött és leírt adatokat. A jelenségek magyarázatához felhasználva a világ nyelvi leképezésének belső mechanizmusát. Az egyes beszélőktől nyert adatok rendszerré állnak össze, melynek általános és egyedi törvényszerüségei rávilágítanak a nyelvhasználó közösségek közötti párhuzamokra.

3. A berlini Magyar Intézetben folyó munka sokszínüségét, nyitottságát jól tükrözi a Magyarországon már-már feledésbe merült nyelvész-tipológus, ERNST LEWY munkássága (HOLFTER 2008 alapján).

LEWY első kapcsolata a magyar nyelvvel 1910-re datálható: Zur finnisch-ugrischen Wort- und Satzbildung címü habilitációs dolgozatához ekkor Budapesten gyüjtött anyagot. Számos finnugor nyelven tudott, ezek közül a legkevésbé a magyart használta. A berlini Magyar Intézetben 1923/24-ben privát docensként finn, észt, mordvin és csuvas nyelvet tanított. 1925-től 1931-ig rendkívüli professzorként, majd 1931-től 1935-ig kinevezett professzorként általános nyelvészetet oktatott. Mentora a humboldti alapokon álló FRANZ NIKOLAUS FINCK berlini nyelvészprofesszor volt, aki - LEWY jellemzése szerint - szembement kora elfogadott nyelvészeti felfogásával. A történeti nyelvszemléletet nem tekintette az egyetlen üdvözítő iránynak (vö. LEWY 1910: 280), nem elégedett meg azzal, hogy a jelen állapotot pusztán a korábbi állapotok mechanikusan levezethető következményének tekintse. Meglátása szerint elengedhetetlen a nyelv s a nyelvet beszélők lelki alkata közötti összefüggés vizsgálata. Hatalmas anyagot gyüjtött össze, ,nem elégedett meg az adatok felhalmozásával és csoportosításával, hanem a jelenségeket müködtető okot kereste” (LEWY 1928: 281).

3.1. LEWYt szakmailag és emberileg is szoros barátság füzte az UJB. másik szerzőjéhez, HUGO SCHUCHARDThoz - szintén FINCK tisztelője -, levelezésük betekintést nyújt a szakmai kérdésekbe, a személyes vonatkozások pedig emberközelbe hozzák őket. Mindketten osztoztak az Újgrammatikus iskola elutasításában: SCHUCHARDT 1885-ös „Ueber die Lautgesetze. Gegen die Junggrammatiker” címü 39 oldalas bírálata egyben programként is értelmezhető: nemcsak LEWYre, de az UJB. teljes nyelvész-gárdájára erőteljes hatást gyakorolt.

Tézisei röviden összefoglalva: 1. A hangtörvények kivételtelenségének bírálatában SCHUCHARDT nem egyszerüen tényekkel operál, hanem különösen élesen rávilágít a szemlélet tarthatatlanságára. Szerinte a jelenségek leírásában figyelembe kell venni az egymást keresztező folyamatokat; a pusztán „kivételes” minősítés elfedi a lényeget. („A kivételes pusztán külsőleges viszonyt jelöl, nem tartalmaz utalást a belsőleg munkáló erökre” SCHUCHARDT 1885: 8.) 2. Az egyes eseteket egyenként és részletesen meg kell vizsgálni, de ezzel még nem ért véget a munka: „Az egyedi jelenségek leggondosabb vizsgálata során sem téveszthetjük szem elől az általánost, a tudományban csak azért kell elmerülnünk, hogy aztán fölé emelkedjünk; csak azért kell szolgálnunk, hogy aztán uralkodjunk rajta" (SCHUCHARDT 1885: 39). Ezzel a célkitüzéssel SCHUCHARDT végeredményben a husserli fenomenológia álláspontját közvetíti: a tudomány feladata, hogy ne pusztán a léttel, hanem a lényeggel foglalkozzon. „A fenomenológusnak nem magukkal a dolgokkal kell törődnie; öt a dolgok jelentése érdekli úgy, ahogyan az elménk tevékenységei által konstituálódik” 
(SCHÜTZ 114). ${ }^{2}$ SCHUCHARDTnak e korai tanulmányában megfogalmazott fenomenológiai nézőpontja és a kognitív megközelítést magában foglaló funkcionális szemlélete között nem nehéz észrevenni a párhuzamot. Ez az egybeesés a módszertanában is fellelhető. 3. „Az egyes jelenségekben meg kell tanulni megtalálni az általánost; egy olyan tény felismerése, mely a teljes nyelvi müködést uralja, fontosabb, mint valamely különleges jelenség leírása" (SCHUCHARDT 1885: 36). 4. Az empirikus adatok, a tények megállapítása nem vezethet leegyszerüsítéshez: az átmenetek vizsgálata világítja meg legjobban a folyamatokat, a lényegre ezekböl lehet igazán következtetni (i. m.13, 31). 5. A nyelvcsoportok között felállított fő határokat pontosan annyira nem tartja követendőnek, mint a rokonság nem rokonság egymást kizáró fogalmát. Ezek mindenkor a kutatás tárgyai; ugyanolyan empírikus megközelítéssel kell vizsgálni mindkettőt. SCHUCHARDTnak ezen írása (1885: 37) szinte summázza az UJB. szerzőinek nyelvészeti felfogását: a té n y e k k ö z ö t t i összefüggések kibontása, az okok és célok magyarázata az e mberi kogníció müködésén keresztül. Külső megfigyelöként, elfogultság és előítéletek nélkül próbálják ki téziseiket - merész kísérleteiket, következtetéseiket elfogódottság nélkül osztják meg egymással. A Magyar Intézet, a berlini miliő alkotó és támogató légkört biztosított tudósai számára, ez a tanulmányokban visszatükröződik.

3.2. LEWY első UJB.-ben közölt írása a 4. kötetben jelent meg a Kisebb közlemények rovatban: A magyar nyelv rövid áttekintése (Kurze Betrachtung der ungarischen Sprache. UJB. 1924. 4: 41-47). A tanulmány szerkezete az induktív argumentáció iskolapéldája. 19 paragrafusba rendezve sorolja fel a magyar nyelv jellemzőit. A morfológiát és a szintaxist nem választja külön, a sajátosságok felsorolásának sorrendje esetlegesnek tünik. LEWY maga is felteszi a kérdést: „Valóban nevezhetjük az ilyesfajta tárgyalást tudományosnak?” A választ maga adja meg: „Történetinek semmiképp sem tekinthető, a történetiséget módszertani okokból kizártuk. Eltekintve attól, hogy bizonyos vonásokat jellemzőnek ítéltünk, a magasabb/szükebb értelemben vett tudományosság kritétiumánk is megfelel. [Bekezdés.] Kimutattuk, hogy a magyar bizonyos sajátosságai összefüggenek, más vonások egymással párhuzamosan futnak. Ez utóbbiak - lehetséges, hogy jelen pillanatban még nincs meg erre a tökéletes magyarázat -, de más viszonyokkal összevetve az összefüggéseknél jelentősebbnek tünnek" (§. 18.).

Az említett sajátosságok röviden: 1. magánhangzó-harmónia; 2. a szótövek világos felismerhetősége, a toldalékok elkülöníthetősége; 3. a személyragozás általános érvényessége igékre és névszókra; a névmások személyragozhatósága; az egyes szám tárgyas $^{3}$ igeragok 1. és 2. személyben megegyeznek a főnév Sg. 1. és 2. személyü birtokos végződésével; az alanyi igeragok többes szám 1. és 2. személyben a Pl. 1. és 2. személyü birtokos végződéssel; 4. tagadóige létezése (nincs, sincs); 5. a többes szám $k$-ja igéknél és névszóknál egyaránt megjelenik; 6. hiányos, ill. a források nem kellő alaposságú ismerete következtében az alanyi és tárgyas ragozás szabályait nem pontosan írja le. „A tárgyas ragozás egy 1., 2. és 3. személyü alany összekapcsolása egy 3. személyü tárggyal; az alanyi ragozás egy 1 . személyü alany összekapcsolása egy 2. személyü tárggyal.” A tárgyas ragozás szoros összefüggésben van egyrészt a fönévvel nem egyeztetett határozott névelővel,

2 SCHUCHARD és HUSSERL kapcsolata: http://schuchardt.uni-graz.at/korrespondenz/briefe/ korrespondenzpatner/1559.

${ }^{3}$ LEWY a subjektive és objektive Konjugation megjelölést használja, mely tükörfordítása az abban az időszakban elfogadott terminusoknak. 
másrészt a mellékmondattal (id. 46); 7. az igekötők helyre vagy akcióminőségre utalnak; az igekötő kerülhet az ige után is; ennek eredményeképp egy nyilvánvalóan szabályozott, jelentéssel bíró, ám mégiscsak szabad szórend jön létre. Alapképlete: a meghatározó megelőzi a meghatározottat (mai terminológiával: balra épülő szerkesztés); 8. az esetragok reális (valódi) jelentéssel bírnak, ugyanúgy a képzők is.

Summázatként összefoglalja azokat a tendenciákat, amelyekbe a párhuzamosan futó tulajdonságok besorolhatók: az igei és névszói oldal hasonlósága; az esetragokkal való takarékosság, a Sg. 3. igerag hiánya, az alárendelő szerkesztés dominanciája, a datívusz helyviszonyjelentése: hegynek megy: ${ }^{4}$

Végkövetkeztetése: „Tipológiai besorolását tekintve a magyar egyértelműen a középmezőnyben helyezkedik el, mint az történeti helyzetéből adódik. Ahogyan ez az UralVolga területéről származó, alárendelő finnugor, ill. uráli nyelvekre jellemző (talán szerepet játszik a Kaukázusban, a csoport-flektáló ${ }^{5}$ és forma-izoláló környezetben eltöltött idő is), elszigetelve a flektáló Európai nyelvektől. Ez nagy vonalakban a nép és a nyelv története. Tehát az ilyesfajta szemlélet is beletorkollhat a történetiségbe"(LEWY 1924: 46).

A szintúgy nagy vonalakban bemutatott Kurze Betrachtung... előgyakorlatnak tekinthető LEWY fömüvéhez, az 1942-ben, már írországi száműzetésében megjelent Der Bau der Europäischen Sprachenhez (LEWY 1964: 108). Hasonló a szinte vázlatos, pontokba szedett, lényegre szorítkozó felépítés, mely a témában kevéssé jártas olvasót-kutatót is komoly szellemi erőfeszítésre kényszeríti. Valószínüleg ez a közlési mód jellemezhette előadásait is: olyannyira fókuszált a mélyebb, lényegi összefüggésekre, hogy a végkövetkeztetéshez vezető út részletekbe menő kifejtését elhanyagolta. Ezzel a módszerrel csak a valóban alapos előképzettséggel és kellő szellemi mozgékonysággal megáldott hallgatókat tudta megnyerni - mint például a filozófus WALTER BENJAMINT. „Nyilvánvalóan mély benyomást gyakorolt BENJAMINRA LEWY leginkább unortodoxnak nevezhető eljárása, amellyel szemináriumain kiválogatta magának az érdeklődő és nyitott hallgatókat. Módszeréhez tartozott, hogy különféle, tekintélytisztelőnek semmiképp sem nevezhető megnyilatkozásokkal illette a nyelvtudomány elismert nagyjait, köztük az általa egyébként nagyra becsült WILHELM VON HUMBOLDTot is, akivel kapcsolatban sajátságos stílusban intézett kérdést a résztvevőkhöz: „Értik ezt? Mert én tulajdonképpen nem.” Majd a következő órán közölte az egyébként igencsak kisszámú hallgatósággal, hogy „Csak azután kezdhetjük el az érdemi munkát, ha megszabadultunk a plebejusoktól” (HOLFTER 2008: 368).

3.3. Nehéz akár csak megközelítően is számba venni azokat a témákat, amelyekkel LEWY munkássága során, vagy akárcsak a Jahrbücher egyes számaiban foglalkozott. Ezek közül mindenképpen kiemelkedik a Possessivisch und passivisch. Nyelvtipológiai meg-

${ }^{4}$ A külföldiek magyartanításánál ugyanezek a grammatikai sajátosságok merülnek fel a tanítás kezdetén, illetve ezek azok, amelyeket idejekorán tisztázni kell (szerzői megjegyzés).

${ }^{5}$ A Gruppenflexion, gruppenflektierende Sprache terminus magyar megfelelőjét nem találtam a szakirodalomban, de még az e témában elismert kutatók sem tudtak segítséget nyújtani. A német kifejezés a nem egyeztetett jelzős szerkezetekre vonatkozik. Pl. a német Ich mag diesen klugen Jungen. mondatban a jelző(k) és jelzett szó egyaránt akkuzatívuszban áll. A magyarban ezzel szemben csak a jelzett szó, a fönév hordozza a kázusvégződést: Kedvelem az okos fiúkat. Kivétel a mutató névmási jelző: Kedvelem ezt az okos fiút. 
jegyzések az igei kifejezésekröl címmel megjelent fejtegetése ${ }^{6}$ (LEWY 1928: 274-289). A kiinduló gondolat az igei és névszói személyjelölésnek ma már alapvető tényként elfogadott párhuzama. E kérdés ebben az időszakban az érdeklődés központjába került: a Jahrbücher szerzői közül többen foglalkoztak vele. FINCK, SCHUCHARDT, WINKLER polemizálásába kapcsolódott be LEWY, aki magát a címet is SCHUCHARDTtól kölcsönözte (SCHUCHARDT 1921). LEWY nem vitatja WINKLER megállapítását, mely szerint a „várom végződése ugyanaz, mint a birtokos jelölése" (LEWY 1928: 275), de ennyivel nem elégszik meg; ugyanitt hiányolja, hogy idősebb kollégája megfeledkezett az objektumra (tárgyra) való utalás funkciójáról ${ }^{7}$.

A téma - azaz az ige és a névszó határainak életlensége - korábban a nyelv eredetével kapcsolatban merült fel. Később az eredet-rokonság kérdése háttérbe szorult, s maga a jelenség magyarázata izgatta a kor nyelvészeit. SCHUCHARDT maga is hivatkozik HUMBOLDT példáira: „,egy igei fogalomhoz egy rövidített formában álló névmási alak kapcsolódhat, amely egy függő esetben (Casus obliquus) álló személyre utal, és ugyanez helyettesíti a birtokos névmást: 'az általa végrehajtott nézés vagy a nézése" (SCHUCHARDT 1921: 661; SCHUCHARDT HUMBOLDT Über die Kawi-Sprache auf der Insel Jawa 1838-as 2. kiadásából hozza a példáit, 396).

LEWY folytatja a FinCK és SCHUCHARDT (FINCK1907; SCHUCHARDT 1905, 1921) által felvetett gondolatmenetet: a birtokos szerkezetté alakítható igetartalmat tovább elemzi, $\mathrm{s}$ ennek alapján kategóriákat állít fel, melyek közelítenek a mai terminológia szerinti igenemek szerinti felosztáshoz. A csoportok a következők: 1. a posszesszív csoport (az igei tartalom valakinek a tulajdona); 2. a passzív csoport (tranzitív igék esetében az igei tartalom nem feltételez cselekvőt); 3. az érzékelést kifejező igei tartalmak; 4. az indifferens (később ScHUCHARDt által szubjektívnek nevezett csoport).

LEWY érdeme, hogy az összegzésen, az egymással többé-kevésbé egyezö, ám bizonyos pontokon ütköző állítások tisztázásán túl logikus gondolatlánccá füzte össze a nézeteket, összevetette FINCK és SCHUCHARDT különböző típusú nyelvekből vett adataival, s ennek eredményeként gyakorlatilag leírta az ergatív nyelveket. Módszere a legtisztább értelemben vett funkcionális tipológia: adatgyüjtés, az adatok értékelése, az összefüggések megállapítása, s végül az okok keresése.

Szemléletéről - mely mintaszerü megfogalmazása a külső perspektívának - saját maga vall: „A nyelvi jelenségeket csak azáltal tudjuk elemezni és kategorizálni, ha a nyelvet »tanuljuk«; ezáltal jutunk el odáig, hogy egy bizonyos fokig »bírjuk« azt. Így érjük el azt, amit közönségesen »nyelvérzékként« tartanak számon, azaz tudunk bánni az analógiás és metaforikus sorokkal, amelyek a nyelv alakját és jelentését kormányozzák [... ]. A saját nyelvünket illetően rendelkezünk azzal a képességgel, hogy eldöntsük, mi a helyes, de ezáltal még korántsem jutottunk el az elemzésig. Még a nap mint nap használt grammatikai

${ }^{6}$ Szándékosan nem fordítottam le, mert nem tudom visszaadni a tömör, formájában és hangzásában is sokat mondó címet. A szó szerinti fordítás: Birtokló és szenvedő (szerkezetek) sem a pontos terminológiát, sem a hangalakban rejlő akusztikus hatást nem adja vissza. Fontos és nehéz vállalkozás lenne a teljes tanulmány lefordítása.

${ }^{7}$ LEWY cseremisz nyelvtanában (1922) részletesen taglalja a finnugor nyelvekben megjelenő kétféle ragozás funkcióját, eredetét; keresi a lehetséges kapcsolódási-összehasonlítási pontokat az indoeurópai nyelvekkel. A grammatikai kategóriákon és szinteken átnyúló szemlélete iskolapéldája a funkcionális megközelítésnek. Részletesebb elemzést 1. KUZNECOVA 1999. Nem csoda, hogy idősebb pályatársán számon kéri e probléma vizsgálatát. 
formákkal kapcsolatban sem rendelkezünk közvetlen, müködő tudással, mellyel megválaszolható lenne a Mi okból és a Mi célból kérdés" (LEWY 1928: 278).

A magyar nyelvészet korai funkcionális irányultságának igazolásaképp érdemes öszszevetni LEWY fenti megfogalmazását BALLAGI MóR 1855-ben írt soraival: „Mikor idegen nyelvet tanúlunk, első tekintetre sok olly sajátság ötlik szemünkbe, mellyekre az, ki a' nyelvet gyermekségétől fogva beszélte, soha nem figyelmezett; amaz már eleve kényszeríttetik a' nyelv' törvényeit tanúlmányozni, hogy megértse [...]. Innen van az, hogy az anyanyelv' szabályaival rendesen csak idegen nyelv’ tanulása' nyomán ismerkedünk meg, és hogy némileg nehezebb az anyanyelv' szabályait, mint idegen nyelv' grammatikáját megírni” (BALLAGI 1855).

4. A berliniek - e megjelölés az UJB. szerzőire vonatkozik tekintet nélkül arra, hogy álltak-e hivatalos, alkalmazotti viszonyban az Intézettel - nemzetközi tudományos kapcsolatrendszere rendkívül kiterjedt volt. Erről tanúskodik AURELIEN SAUVAGEOT Párizsból datált megemlékezése: Zoltán Gombocz und die Erneuerung der Sprachwissenschaft (UJB. 15: 555-560). A pályafutását turkológusként kezdő kutató 1931 és 1934 között tanított francia nyelvet az Eötvös Kollégiumban, ekkor kötött szoros barátságot Gombocz Zoltánnal. Barátja és mentora halálakor írt nekrológjában félreérthetetlenül rátapint Gombocz tudományos teljesítményének lényegére: a funkcionális szemlélet jelentőségének felismerésére. A szakmai közvélemény - kortársak és utódok - hiába próbálták meg besorolni GOMBOCZ munkásságát a történeti összevető nyelvészetet követő strukturalista áramlatba, tevékenységének irányulása nem itt keresendő. „Egy finnugristát vártam, akinél kitanulhatom új tudományágam módszereit és eredményeit. Ehelyett egy olyan nyelvészre leltem, akiben a romanista, az altajista, az elméleti nyelvész és a finnugor nyelvek specialistája versengett az első helyért. [...] A nyelvi rendszer problémái jobban foglalkoztatták a formák történeténél. Figyelme középpontjában korábban a nyelvhasonlítás állt, de mostanra eltávolodott ettől, mivel az összehasonlító nyelvészetbe vetett bizalmát megrendítette az élő nyelv tényeivel való állandó szembekerülés" (UJB. 15: 555-556).

4.1. A továbbiakban érdemes kiemelni SAUVAGEOT élményszerü megfogalmazásából a legfontosabb megállapításokat, melyek GOMBOCZnak a még ma sem kellően méltatott funkcionális alapvetését bizonyítják. Ezek közül számos lényeges gondolat leírására már nem kerülhetett sor, csak a tanítás, illetve beszélgetések során hangzottak el. 1. GOMBOCz letért a Fiatal Grammatikusok által lefektetett útról. Miután bizonyította, hogy tökéletesen tudja alkalmazni a funkció helyett a formára koncentráló módszereiket, már A bolgár-török jövevényszavak a magyarban című tanulmányában is összeköti a nyelvtörténetet a kultúra történetével. Ezzel új perspektívát nyitott a magyar nyelv eredetének kutatásában (i. m. 556). 2. A háború utáni időszakban kiterjesztette kutatási területét az élő nyelvre: a beszélt, írott és gondolt nyelv vizsgálata során eljutott az alapkérdéshez: hogyan tükrözik vissza a nyelvi tények a valóságot? WUNDT, PAUL, SÜTTERLIN, NOREEN, DE SAUSSURE, MEILLET és mások elméleteit összevetetve a saját tapasztalataival megállapította, hogy a nyugat-európai és a magyar szemlélet között feszülő ellentét oka a különböző gondolkodási kategóriák különbségében rejlik. SAUVAGEOT szó szerint leírja a bizonyítási eljárást, mellyel GOMBOCZ az ige és a névszó fogalmát beszélgetéseik során kifejtette. „[H]a kimondom a fagy szót, fogalmam sincs, hogy igével vagy névszóval van-e dolgom. Számomra ez nem is kérdés. Tettem egy kijelentést, mely egy megfigyelt jelenségre 
vonatkozik. A kijelentés a fagy formát ölti magára. Funkciója kétségtelenül predikatív. A formája mellékes” (i. m. 557). „A finnugor nyelvekben az igenévszó szükségszerüen igévé fejlődött, mert mindig predikatív funkcióban használták. A predikatív funkciójú névszók elnevezése ige lett, másik csoportjuk betölthet jelzői, határozói, alanyi, és névszói állítmányi szerepet. A végkövetkeztetés: „A finnugor, török vagy mongol ige kicsinyített névszó, melyeknek csorbultak a jogai, lehet mondani deminutio capitis következett be" (i. m. 558). 3. A leglényegesebb megállapítása GOMBOCZnak a forma és a funkció különbségére vonatkozik. A nyelvtani kategóriák - beszédrészek - a formához tartoznak, ezzel szemben egy szó (mondatrészi) funkcióját a beszédfolyam logikus egymásutánisága adja. $A$ víz forr és a meleg a víz esetében egyszer igei, másodszor névszói állítmánnyal állunk szemben: szintaktikailag azonos, ám morfológiailag különböző szintaktikai csoportról van szó. A szintaktikai csoport GOMBOCZ elnevezésében a szintagma, amely egy bizonyos szintagmatikus kapcsolatot fejez ki. Bizonyos nyelvekben - pl. magyar, török, mongol - a szórend határozza mega e kapcsolat természetét. Bizonyos esetekben a szintagma nyomatékstruktúrája - Akzentuationsstruktur - és az artikuláció is szerepet játszik. 4. Az előzőekből adódik a nyelvtípusoknak egy lehetséges osztályozása: az indoeurópai nyelvekben csak ige lehet predikátum, míg más nyelvekben (pl. a kínaiban) a mondatbeli hely határozza meg a szintaktikai funkciót (i. m.558).

A funkció-fogalom vizsgálata GoMBOcznál nem korlátozódik nyelvtanra. Leszögezi, hogy a nyelvekben fellépő mindenfajta struktúraváltás oka a funkcióban keresendő: „Ez az oka minden titokzatos nyelvi változásnak, melynek okát a Fiatal grammatikusok hiába keresték, s végül rezignáltan megismerhetetlennek minősítették” (i. m. 559).

Utolsó éveit GOMBOCZ e témának, a nyelvi forma és a belső szerkezet összefüggéseinek szentelte. Ez volt funkcionális nyelvészeti kutatásának alaptétele, ennek alapján szándékozott leírni anyanyelve történetét. Magába a nyelv szerkezetébe - meglátása szerint - már sikerült behatolnia, a mozgásokat megragadnia. E mozgás az elme számára még megfoghatatlanabb, mint a mechanikus mozgások. A nyelvésznek, aki mindezekről számot akar adni, még bonyolultabb egyenleteket kell felállítania, mint a fizikusnak a testek mozgásának definiálásához" (i. m. 559).

A nekrológ végszavaként SAUVAGEOT lehetségesnek tartja, hogy rejtett fiókok mélyéről még előkerüljenek e témába vágó írások; addig is az utókor kötelessége, hogy folytassa a kutatást. „A funkcionális nyelvészet hozhatja meg számunkra a vágyott megújulást" - adja meg a végszót, s egyben a választ a modernség és tradicionalizmus problematikájára az Ungarische Jahrbücher nyelvészeti írásaiban.

5. Összegzés. Általánosan elfogadott vélemény szerint a nyelvtudomány fejlődését a HuMBOLDT-SAUSSURE-CHOMSKY egyenes fémjelzi. Ha ezen a vonalon próbáljuk elhelyezni az Ungarische Jahrbücher nyelvészeit, nem kecsegtet siker. Mintha HUMBOLDT után, valahol a Fiatal grammatikusok körül kétfelé ágazna ez a vonal: míg a CHOMSKYhoz vezető út a csupasz forma területén végez mélyfúrásokat, addig a HUMBOLDT által elindított empirikus-tipológiai irány gazdagodik a szemantika és pragmatika értékeivel.

Az Ungarische Jahrbücher nyelvészeti tanulmányaiban már az első évtized vége felé körvonalazódtak a célok: a nyelvtörténeti vizsgálódás hangsúlya az eredet-rokonság kérdéséről áttevődött a funkcionális-tipológiai szemléletű feltárásra. Az adatgyüjtés és -feldolgozás célja nem pusztán a genetikai vizsgálódás volt, megjelentek a szinkrón és a földrajzi szempontok is. 
A Mi célból? és Mi okból? kérdések megválaszolására skrupulus nélkül nyúltak a szerzők akár a legtávolabbi nyelvekből nyert adatokhoz. Felismerték, hogy a hagyományos kategóriák szorításán (vö. SCHUCHARDT 1921: 661) csak újabb és újabb összefüggések feltárásával lehet lazítani. Ahhoz, hogy a tradíció - modernség kérdését alaposabban megvilágítsuk, egy kifejezetten ezzel a témával foglalkozó tanulmányt hívtam segítségül.

5.1. HASS-ZUMKEHR (2000) bevezetésként szemantikai vizsgálattal igyekszik a lehető legpontosabban meghatározni a modernség mibenlétét. Mindkét melléknévhez - tradicionális, modern - egyaránt kapcsolódhatnak pozitív és negatív konnotációk. A tradicionális lehet konzervatív és idejétmúlt, de ugyanakkor klasszikus és megőrző is. Kétségtelen, hogy a modern esetében több a pozitív szinonima, de ugyanakkor idetartozik a steril vagy a technicista is. Ezért a szerző a szemantika megközelítés helyett inkább kritériumokat állít fel. Ezek szerint modernnek tekinthető a nyelvészeti irány, ha 1. egyre több ismeretet halmoz fel a nyelvröl; 2. ugyanazokat a problémákat új szempontok hozzáadásával dolgozza fel; 3. a területét egyre szélesebbre bővíti.

Elsődleges kritériumként a KUHN nevével fémjelzett tudományos forradalmat jelöli meg (HASS-ZUMKEHR 2000: 62). Az UJB. nyelvészei első megközelítésben meglehetősen távol állnak a forradalmi hevülettől s a forradalmakkal szükségszerüen együtt járó rombolástól. A szerzők különböző vérmérsékletét figyelembe véve is a kiegyensúlyozott, nem személyeskedő, a tárgy minél alaposabb megismerésére való törekvés jellemezte írásaikat. A paradigmaváltás a megismerés egyre mélyülő fokozatainak megfelelően lépésről lépésre ment végbe, mígnem beletorkollott egy külső nézőpontú, a funkciót kulcsfogalomként kezelő keretbe. Ebben a keretben új megvilágításba kerültek a nyelvtörténet összefüggései, magyarázatot kaptak a Fiatal grammatikusok által megfejthetetlennek tartott jelenségek. A nyelv belső mozgásának feltárásában a forma csak másodlagos szereplő; a karmesteri pálca maga a funkció. Hogy a pálcát mi mozgatja, arra szintén egy Berlinhez köthető szerző, THIENEMANN TIVADAR késői müve ad magyarázatot. ${ }^{8}$ Eredetileg Amerikában, angolul megjelenő kétrészes müvének: The Interpretation of Language 1. Understanding the Symbolic Meaning of Language; 2. Understanding the Unconscious Meaning of Language kiindulása a nyelv jeltermészetének továbbértelmezése. Szerinte a nyelv nem pusztán jel, hanem szimbólumrendszer. A jelentésváltozás metaforikus úton következik be, s e folyamaton belül a régi szimbólumok tudattalanul tovább élnek. A nyelvek különbségének megértéséhez szükség van a szimbólumok megfejtéséhez. Kétséget kizáróan bizonyítja a berlini mühely nyitottságát, ahogyan THIENEMANN a német jövevényszavaktól indult, s eljutott a nyelvi jelek szimbólumtartalmához - ezáltal kapcsolódva az irodalomtudományhoz.

Az egyes tanulmányok bemutatásával tárgyszerủen igyekeztem rámutatni az UJB. nyelvészeti szemléletének modernségére: a tradicionális összehasonlító nyelvészetéböl kiindulva, azt feldolgozva és azt meghaladva eljutottak a nyelvhas ználat leírását célzó funkcionális nyelvészetig. Haladó az empíriára támaszkodó praktikus szemlélet, mely megteremti a maga elméletét. Az utókor feladata, hogy ne hagyja feledésbe merülni a magyar nyelv perspektívájából nyert eredményeket, ne rendelje azokat alá a divatos áramlatoknak.

${ }^{8}$ Ezúton is szeretném kifejezni köszönetemet THASS-THIENEMANN műve (2016) kiváló fordítójának, SIMONCSICS PÉTERnek, aki felhívta a figyelmemet THIENEMANN e munkájára. 
Kulcsszók: történeti-összehasonlító nyelvészet, funkcionális-kontrasztív megközelítés, kognitivizmus, Ungarische Jahrbücher, Berlin.

\section{Hivatkozott irodalom}

BALlAGI MóRICZ 1855. A' magyar szónyomozás, 's az összehasonlító nyelvészet. Új Magyar Múzeum 5: 590-591.

FEHÉR KRISZTINA 2018. A nyelv grammatikája. A nyelvtudomány és a kognitiv pszichológia. Debreceni Egyetemi Kiadó, Debrecen.

FinCK, Franz NiKolaus 1907. Der angeblich passivische Charakter des transitiven Verbs. Zeitschrift für vergleichende Sprachforschung auf dem Gebiete der Indogermanischen Sprachen 41: 209-282.

Gombocz ZoLTÁN 1912. Die bulgarisch-türkischen Lehnwörter in der ungarischen Sprache. Société Finno-Ougrienne, Helsinki.

GRAGGER, ROBERT 1921. Unser Arbeitsplan. Ungarische Jahrbücher 1: 1-8.

GRAGGER, ROBERT 1925. Die ungarische Universität. Ungarische Jahrbücher 5: 25-40. http://mek. oszk.hu/17900/17907/17907.pdf (2019. 01.20.)

HEGEDÜS RITA 2018. Tradíció és modernség az Ungarische Jahrbücher nyelvészeti írásaiban. 1. rész. Magyar Nyelv 114: 78-86.

HofTer, GiSEla 2008. Akademiker im irischen Exil: Ernst Lewy (1881-1966). https://www. academia.edu/3982609/Akademiker_im_irischen_Exil_Ernst_Lewy_1881-1966_1 (2016. 11. 02.)

KIEFER FERENC 2002. Nyelvtudományi irányzatok az Akadémián (Linguistic trends at the Academy). In: GLATZ FerENC szerk., Közgyülési elöadások 2000. Az MTA 175 éve. MTA, Budapest. 11-24.

KuZnecova, Margarita 1999. Das Verb im Tscheremissischen. Zum Problem der Entstehung der zwei Konjugationen. Linguistica Uralica 35: 279-289.

LEWY, ERNST 1910. Zur finnisch-ugrischen Wort- und Satzbildung. Vandenhoeck \& Ruprecht, Göttingen.

LEWY, ERNST 1922. Tscheremissische Grammatik. Darstellung einer wiesentscheremissischen. Mundart, Leipzig.

LEWY, ERNST 1942/1964. Der Bau der Europäischen Sprachen. Max Niemeyer Verlag, Tübingen.

LEWY, ERNST 1928. Possessivisch und Passivisch. Ungarische Jahrbücher 8: 274-289.

SAUVAGEOT, AURELIEN 1935. Zoltán Gombocz und die Erneuerung der Sprachwissenschaft. Ungarische Jahrbücher 15: 555-560.

SCHUCHARDT, HUGO 1885. Ueber die Lautgesetze. Gegen die Junggrammatiker. Oppenheim, Berlin.

SCHUCHARDT, HUGO 1895. , Über den passiven Charakter des Transitivs in den kaukasischen Sprachen". Sitzungsberichte der philosophisch-historischen Classe der Kaiserlichen Akademie der Wissenschaften 133. Kais. Akademie der Wissenschaften, Wien. http://schuchardt.uni-graz.at/ id/publication/166.pdf, (2018. 01. 02.)

SchuchardT, Hugo 1921. Possessivisch und Passivisch. In: Sitzungsberichte der preußischen Akademie der Wissenschaften 39. Verlag der Akademie der Wissenschaften, Berlin. 651-662. http://schuchardt.uni-graz.at/id/publication/337.pdf. (2019. 01. 02.)

SCHÜTZ, ALFRED 1984. A fenomenológia néhány vezérfogalma. In: HERNÁdi MikLós szerk., Fenomenológia a társadalomtudományban. Gondolat, Budapest.

Thass-THIENEMANN, TIVAdAR 2016. A nyelv interpretációja I. A nyelv szimbolikus jelentése. Tinta Kiadó, Budapest. 


\section{Tradition and modernity in papers on linguistics in Ungarische Jahrbücher}

\section{The emergence of the functional perspective in the Berlin school}

The 20th century has brought interesting changes in the humanities. Comparative-Historical Linguistics has reached its peak, and the paradigm framework has begun to come apart. Today we can see the following tendency: the main trends - at least for a while - have been taken over by formal theories: structuralism and generativism. The mainstream of Hungarian linguistics belonged to the German lineage and tried to connect to the trends established by Saussure and Chomsky. The functional-contrastive approach has been neglected for a long time, but it is finally leading to a definitively cognitive approach. A very important incubator of this development was the Institute for Hungarian Language in Berlin. My paper focuses on its activity in the light of scientific articles in the journal "Ungarische Jahrbücher".

Keywords: Comparative-Historical Linguistics, functional-contrasive approach, cognitivism, Ungarische Jahrbücher, Berlin.

HEGEDÜS RITA

Humboldt Universität, Berlin Károli Gáspár Református Egyetem

\section{SZEMLE}

\section{Három körösztyén leány. Az első magyar nyelvü dráma}

A magyar nyelvü átiratokat készítette és a tanulmányt írta DöMÖTÖR ADRIENNE. A latin szöveget átírta, fordította és a latin nyelvü változatokkal kapcsolatos jegyzeteket írta SzENTGYÖRGYI RudOLF. Balassi Kiadó, Budapest. 127 lap

A címben jelzett, tíz lapnál alig hosszabb drámai emléket, a műfaj első fennmaradt magyar nyelvű darabját a Sándor-kódex (21/1-31/6) örizte meg. A magyar változat ismeretlen szerzője a 10. században élt Hrotsvitának, a kelet-szász gandersheimi bencés apátság kanonisszájának latin nyelvü munkáját - melyet az utókor Dulcitius néven ismer - ültette át. A jelen kiadvány nem egyszerü szövegközlés, ahogy a címéből vélhetnénk, nem is - mint kódexeink esetében szokás - a magyarnak a latin forrással párhuzamba állított bemutatása, hanem olyan szövegösszeállítás, amely a régi kéziratoktól kezdve a szöveg mai, könnyebben befogadható változatáig vezeti el az olvasót, illetve vezeti be a hagyományozódás sokszor kifürkészhetetlen útjaiba. A részben az érdeklődő olvasóknak szánt, de a szakembereknek is szóló kötet jól példázza ily módon a nyugat-európai latin nyelvű keresztény kulturális javak átörökítésének, valamint a humanisták ebben vállalt szerepének egy lehetséges módját is. Érdekessége még, hogy a latin mű első nemzeti nyelvű fordítása-átdolgozása - az eredeti után körülbelül öt és fél század múlva - éppen magyarul szólalt meg.

A kiadvány külön-külön mutatja be előbb a magyar, majd a latin dráma szövegét, $\mathrm{s}$ az összevetésük megkönnyítésére mindegyiket több, egymást hasonló logika szerint kö- 